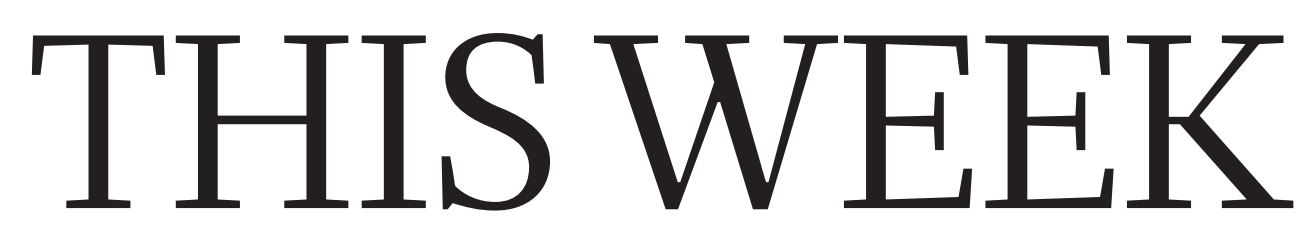

EDITORIALS

WORLD VIEW Not So fast, science is far from saved $\mathbf{p} .133$

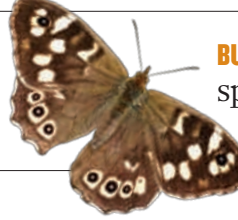

BUTTERFLIES British

species flutter by earlier

each year $p .134$
BARRIER GRIEF Australian floods could bring surge in coraleating starfish $\mathbf{p . 1 3 6}$

\title{
Think big
}

\section{The best way to manage national parks in the face of the effects of climate change is not to manage at the park level, but to work with landscapes. A new US initiative shows the way.}

I n 1882, the US conservationist George Bird Grinnell wrote about humans invading natural habitats as "the tide of immigration" that was then sweeping across the American West. "There is one spot left, a single rock about which this tide will break, and past which it will sweep, leaving it undefiled by the unsightly traces of civilization." That rock was Yellowstone National Park, then just ten years old.

Thanks in large part to the success of Yellowstone, this rocksin-the-tide or 'protected area' model has been adopted worldwide. Yellowstone remains the archetype for the park as an island in space and time, walled-off from changes to the land around it. But any park scientist or manager will tell you that to freeze a park in time is an unattainable ideal. And for better or worse, parks cannot be completely isolated in space either. Yellowstone is surrounded by national forests, ranches, game refuges and other natural lands that are ten times the size of the park itself, as well as by the spawning tendrils of residential development. European spotted knapweed gets in and grizzly bears get out.

As the effects of global climate change begin to unspool, park managers at Yellowstone and around the world are deciding how to proceed, torn between their impulse to fight to keep ecosystems the way they are and a reluctance to fiddle with nature too much (see page 150).

Perhaps the best approach is for them to ponder instead the larger landscape in which their parks sit. Scaling up is reassuring. At the park level, climate change may extirpate a species. At the landscape level, climate change merely moves it. And scaling up is more effective. Ecologists and conservation biologists have known for decades that small isolated parks leak species. Smaller populations have smaller gene pools in which maladapted traits are more likely to become fixed. Smaller populations are more vulnerable to drought, pests, hard winters or simple bad luck.

This is why conservation biologists, since at least the early 1990s, have called for parks to be connected to one another by unbroken corridors of nature, through which large species can move. For small mobile species, such as birds and insects, a stepping-stone scatter of protected areas close to one another has much the same effect. Climate change makes such connectivity even more important, as species challenged by the changing climate will need big gene pools to draw from and lots of different places to which they can move to. In particular, sites with microclimates to harbour species that can't take the heat need to be identified, protected and linked to existing protected areas.

As corridor ecology has taken off as a scientific subfield, so have corridor and connectivity projects such as the Yellowstone to Yukon Conservation Initiative in North America and the Australian Alps to Atherton Connectivity Conservation Area. Britain's Royal Society for the Protection of Birds is restoring lands beyond nature reserves in its Futurescapes programme. Some projects are even species-specific, such as Protecting the Pronghorn Path - a 240-kilometre-long federally designated and protected 'migration corridor' put in place on

all the different lands that the American antelope crosses on its way between summer and winter ranges in Wyoming. As the pronghorns make their way back and forth, the ungulates traipse across national forests, Bureau of Land Management gas fields, private cattle ranches and state-owned roads, where the department of transportation is this winter installing pronghorn-friendly underpasses. Coordinating

"It would be unforgivable to lose

honeyeaters, antelopes, grizzlies and orchids." all of those players is a massive job, one that was tackled in this case by the Wildlife Conservation Society, based in New York. But there is not the money to do for the whole of Earth what the society was able to do in Wyoming.

In February 2010, the US Department of Interior ordered all the land-management agencies it oversees to join with other federal, state and private land managers in landscape conservation cooperatives' to help to understand and respond to the effects of climate change. At a recent scientific meeting in Yellowstone, many scientists groaned at the prospect of yet another entity in the already crowded and confusing realm of conservation planning. But if these cooperatives are widely embraced, they could be a way to move beyond the truism that landscape-level conservation is needed, and start to do it.

It would be unforgivable to lose honeyeaters, antelopes, grizzlies and orchids, not because scientists didn't know how to save them, but because they were mired in bureaucratic mud..

\section{Different strokes}

\section{Scientists in Romania and Bulgaria are having the best and the worst of times.}

$\mathrm{M}$ arine geologist Liviu Giosan has lived through history. As a student in Romania he took part in the December 1989 demonstrations that brought down the communist government. Just months earlier, no one in the deeply isolated country would have believed that the hated dictatorship could ever fall. Yet the euphoria lasted barely six months. In June 1990, miners joined troops in violently crushing the street protests by students demonstrating against the communist presence in the newly elected government. After he got his degree in 1993, Giosan left for the United States to build a scientific career for himself - something he knew he couldn't do at home. He is now an associate scientist at Woods Hole Oceanographic Institution, Massachusetts.

Most of the brightest young scientists in Romania - and 